Article

\title{
Mechanical Properties and Microstructure of Fibre-Reinforced Clay Blended with By-Product Cementitious Materials
}

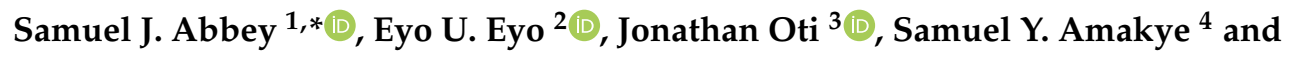 \\ Samson Ngambi ${ }^{2}$ \\ 1 Civil Engineering Cluster, Department of Geography and Environmental Management, Faculty of \\ Environment and Technology, University of the West of England, Bristol BS16 1QY, UK \\ 2 School of Energy, Construction and Environment, Faculty of Engineering, Environment and Computing, \\ Coventry University, Coventry CV1 5FB, UK; eyoe@uni.coventry.ac.uk (E.U.E.); \\ apx290@coventry.ac.uk (S.N.) \\ 3 School of Engineering, Faculty of Computing, Engineering and Science, University of South Wales, Trefforest, \\ Pontypridd CF37 1DL, South Wales, UK; jonathan.oti@southwales.ac.uk \\ 4 Ph.D. Candidate Civil Engineering Cluster, Department of Geography and Environmental Management, \\ Faculty of Environment and Technology, University of the West of England, Bristol BS16 1QY, UK; \\ Samuel.Amakye@uwe.ac.uk \\ * Correspondence: samuel.abbey@uwe.ac.uk
}

Received: 6 May 2020; Accepted: 19 June 2020; Published: 21 June 2020

\begin{abstract}
Clayey soils endure adverse changes in strength and volume due to seasonal changes in moisture content and temperature. It has been well recognised that high cement content has been successfully employed in improving the mechanical properties of clayey soils for geotechnical infrastructural purposes. However, the environmental setbacks regarding the use of high cement content in soil reinforcement have necessitated the need for a greener soil reinforcement technique by incorporating industrial by-product materials and synthetic fibres with a reduced amount of cement content in soil-cement mixtures. Therefore, this study presents an experimental study to investigate the mechanical performance of polypropylene and glass fibre-reinforced cement-clay mixtures blended with ground granulated blast slag (GGBS), lime and micro silica for different mix compositions and curing conditions. The unconfined compressive strength, linear expansion and microstructural analysis of the reinforced soils have been studied. The results show that an increase in polypropylene and glass fibre contents caused an increase in unconfined compressive strength but brought on the reduction of linear expansion of the investigated clay from $7.92 \%$ to $0.2 \%$ at fibre content up to $0.8 \%$ for cement-clay mixture reinforced with $5 \%$ Portland cement (PC). The use of $0.4-0.8 \%$ polypropylene and glass fibre contents in reinforcing cement-clay mixture at $5 \%$ cement content causes an increase in unconfined compressive strength (UCS) values above the minimum UCS target value according to American Society for Testing and Materials (ASTM) 4609 after 7 and 14 days curing at $20^{\circ} \mathrm{C}$ to $50^{\circ} \mathrm{C}$ temperature. Therefore, this new clean production of fibre-reinforced cement-clay mixture blended with industrial by-product materials has great potential for a wide range of applications in subgrade reinforcement.
\end{abstract}

Keywords: cement-clay mixture; ground granulated blast slag; micro silica; polypropylene fibre; glass fibre; elevated temperature

\section{Introduction}

Soil stabilization has been proven to be a technically effective and economically viable means of achieving a safe and stable ground for crucial development activities [1-4]. It is essentially a 
method of ground improvement that involves the chemical alteration of weak soil properties in order to meet some specific mechanical or engineering requirements such as strength, swelling and durability [5]. The chemicals or binders often used traditionally for the stabilization of problematic soils are lime and cement and it is pertinent to state that the usage of these traditional binders has raised key environmental issues as a result of their high energy consumption and outputs, carbon dioxide emission and the depletion of resources [6]. In recent decades, potential substitutes (industrial wastes, by-products materials, polymers, organics products) to the traditional binders (lime and cement) have been considered by researchers and industries for the stabilization of soft expansive soils [2,7-11]. These materials have now become very competitive economically and technically, and their usage does ensure environmental sustainability. Even though some of these materials are pozzolanic as far as soil stabilization is concerned, others may still require activators to enable them to be more effective in their functions. Ground granulated blast furnace slag (GGBS) for instance is a common by-product generated in the steel production process and has been used as an agent either solely or in combination with lime, cement, etc. for the stabilization of weak expansive soils [5,12-14]. Attention has also shifted to the consideration of polymers for use in stabilization in geotechnical engineering in recent years and their applications in soil improvement spans various areas including in expansive soils, tunneling, landfill lining, geological barriers etc. [15-18]. The utilization of geosynthetic or polypropylene for instance as reinforcement in compacted expansive soils has led to the reduction in tension cracking and controlled volume changes as a result of swelling and shrinkage [19-30]. In these studies, fibre length was suggested as one of the main factors that can bear a significant influence on the properties of the stabilized soil. but it has been proven that relatively long fibres could weaken the soil and encourage swelling of the soil [31]. Glass fibre is another material with excellent properties including strong heat resistance, good corrosion resistance, high tensile strength [32]. It is commonly used as a reinforcement material in a composite material [32]. The use of glass fibre as an agent in the improvement of weak soils are found in literature [33,34]. Another potentially desirable soil binder is micro silica which is a by-product material resulting basically from the reduction of high-purity quartz with coal in an electric arc furnace during the manufacture of silicon or ferro-silicon alloy can be used as a pozzolana. This product is processed and sold in powdered form even though it is more commonly available in liquid. Few research works have investigated the effect of using micro silica on the geotechnical properties of expansive soils [35-40]. Al-azzawi et al. [36] investigated the effect of micro-silica on the soil subgrades of inadequate natural stability. The clay-micro-silica mixtures were compacted at their various optimal conditions and then subjected to engineering tests. Micro-silica led to an increase in improvement of the consistency limit properties and a decrease in the specific gravity for all the clay samples tested and with $4 \%$ of the additive. A significant improvement in swell performance and compressive strength of composite samples were also noted by using micro-silica. The swell pressure reduced by $87 \%$ when micro-silica was increased from $5 \%$ to $15 \%$ by weight of the samples. Undoubtedly, cement in the range of 8-20\% [41] has been widely used in enhancing the mechanical behaviour of weak and expansive soils but despite being a fantastic building material, there have been some sustainability concerns with Portland cement (PC), especially in relation to the growth in greenhouse gas (GHG) emissions. Which can be attributed to the intensive energy requirement for its production with an approximate of 1 tonne of carbon dioxide $\left(\mathrm{CO}_{2}\right)$ released into the environment for each tonne of cement produced. In 2018, there was an increase in global GHG emissions of about $2 \%$ mainly due to a $2 \%$ increase in global fossil $\mathrm{CO}_{2}$ emissions from the combustion of fossil-fuel and those from industrial non-combustion processes including cement production. Therefore, motivated by the environmental setbacks regarding the use of high cement content in soil stabilization and the limited research in the use of a combination of green industrial by-products (GGBS and micro silica) and synthetic fibres, in the soil stabilization process, this study has set out to study the performance of polypropylene and glass fibre reinforced cement-clay mixtures blended with GGBS, lime and micro silica for different mix compositions and curing conditions. 


\section{Scope of Study}

This study is intended to contribute to the understanding of unconfined compressive strength (UCS) and linear expansion of polypropylene and glass fibre reinforced clay blended with GGBS, micro silica and lime. The clay was stabilised with a low binder content and reinforced with polypropylene and glass fibres. To this end, three types of test were carried out: unconfined compressive strength (UCS) tests, linear expansion test, and scanning electron-microscope test (SEM). The study focuses on the analysis of the effect of accelerated curing temperature, binder quantity, both with and without fibres and the effect of the fibre quantity on the compressive and swelling behaviour of the reinforced clay. At reduced cement content and inclusion complimentary cementitious binders and fibres, the UCS values of the reinforced clay were compared with the minimum target of UCS for stabilised soils as recommended by the American Society for Testing and Materials (ASTM) 4609. The ASTM D 4609 (Standard Guide for Evaluating Effectiveness of Admixtures for Soil Stabilization) suggests that if an increase in UCS of $345 \mathrm{kPa}$ or more due to treatment occurs, or if no significant strength is lost due to soaking, then the treatment may be considered effective. Therefore, the UCS values of the fibre treated soil in the present study will be compared to the value provided by the ASTM D 4609 to ascertain the level of improvement.

\section{Materials and Method}

The materials used in this study were kaolin clay, Portland cement (PC), lime, supplementary cementing materials (SCM) (GGBS and micro silica (MS)), and polypropylene (PPF) and glass fibre (GF). In terms of their main constituents, the PC and lime used comply with BS EN 197-1:2011 (BSI, 2011a) and BS EN 459-1:2015, and the chemical properties of the materials are as provided by the manufacturers respectively. Two by-product supplementary cementitious materials (GGBS and micro silica) were used for this study to contribute to the properties of the treated soil through hydraulic or pozzolanic activity. Preliminary classification test such as Atterberg limit and compaction test conducted on the clay soil is presented in Table 1. Figure 1 shows result of the particle size distribution test conducted on the materials using the laser particle size analysis method. The chemical compositions of the materials are presented in Table 2. The polypropylene used is a synthetic material with resistance to alkalis, chloride and chemical and are non-corrosive and hydrophobic, and was supplied by Helios drive, Baglan Energy, Port Talbot, UK. The glass fibre used is also an alkali-resistant glass fibre and was supplied by Fibre Technologies International Avonmouth, Bristol. Glass fibre is a material with excellent properties, it has random network structure composed of $\mathrm{Sio}_{4}$ tetrahedra. It has a perfect insulating behaviour, excellent corrosion resistance, strong heat resistance and high tensile strength (1950-2050 MPa). A $12 \mathrm{~mm}$ length and 12-13 $\mu \mathrm{m}$ diameter polypropylene fibres and $10 \mathrm{~mm}$ length and $14 \mu \mathrm{m}$ diameter glass fibres were used.

Table 1. Consistency limits and other properties of kaolin clay.

\begin{tabular}{lc}
\hline \multicolumn{1}{c}{ Soil Property } & Value \\
\hline Consistency Limits & \\
Liquid limit $w_{L}(\%)$ & 56 \\
Plastic limit $\mathrm{wP}(\%)$ & 26 \\
Plasticity index Ip(\%) & $30 \mathrm{ZZ}$ \\
\hline Others & \\
\hline Specific gravity & 2.6 \\
Expansion index, EI & 58.4 \\
Potential expansion & Medium \\
Maximum dry Density $\left(\mathrm{kg} / \mathrm{m}^{3}\right)$ & 1430 \\
timum moisture content $(\%)$ & 27 \\
\hline
\end{tabular}




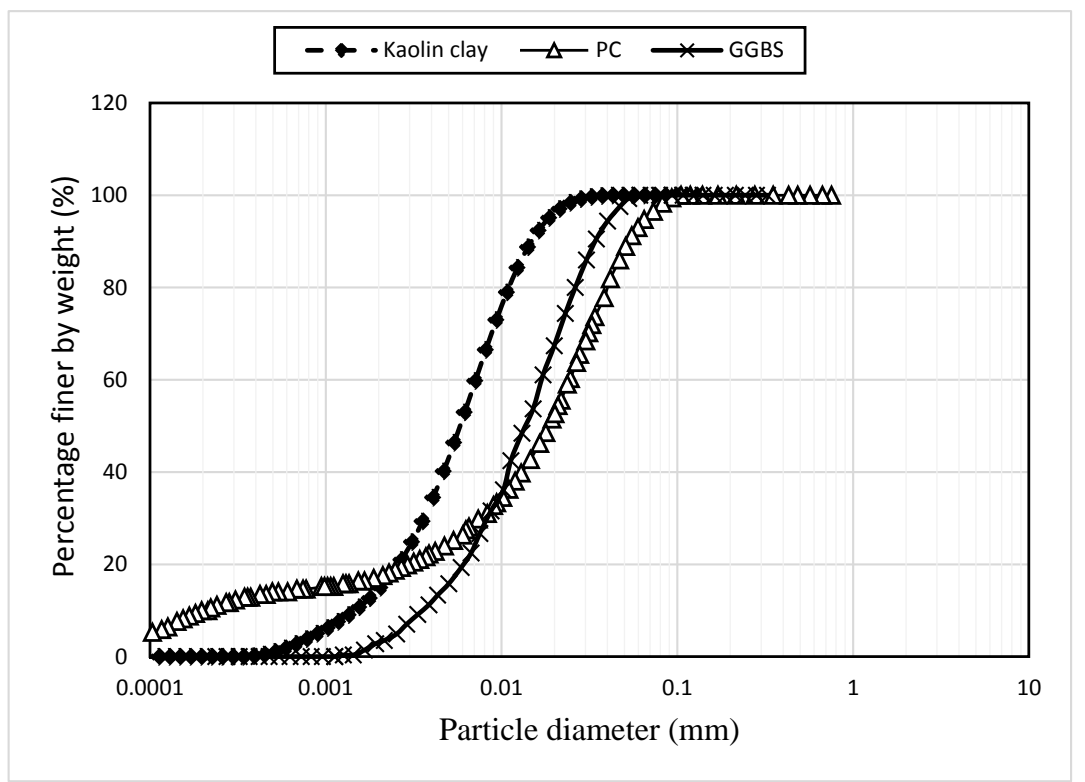

Figure 1. Distribution of particle size.

Table 2. Chemical composition of materials.

\begin{tabular}{ccccccccccccc}
\hline \multirow{2}{*}{ Materials Used } & \multicolumn{10}{c}{ Oxides (\%) } \\
\cline { 2 - 14 } & $\mathbf{S i O}_{2}$ & $\mathrm{TiO}_{2}$ & $\mathrm{Al}_{2} \mathbf{O}_{3}$ & $\mathbf{F e}_{2} \mathbf{O}_{3}$ & $\mathbf{M n O}$ & $\mathbf{M g O}$ & $\mathbf{C a O}$ & $\mathbf{N a}_{2} \mathbf{O}$ & $\mathbf{K}_{\mathbf{2}} \mathbf{O}$ & $\mathbf{P}_{2} \mathbf{O}_{5}$ & $\mathbf{S O}_{3}$ & LOI \\
\hline Clay & 48.00 & 0.02 & 37.00 & 0.65 & - & 0.300 & 0.07 & - & 1.60 & - & - & 12.5 \\
\hline Portland cement & 20.00 & - & 6.00 & 3.0 & 0.09 & 4.21 & 63.0 & - & - & 0.20 & 2.30 & 0.80 \\
\hline GGBS & 33.28 & 0.57 & 13.12 & 0.32 & 0.316 & 7.74 & 37.16 & 0.33 & 0.474 & 0.009 & 2.21 & 4.42 \\
\hline Micro silica & 90.6 & $<0.1$ & 1.47 & 1.93 & - & 0.42 & 1.52 & 0.63 & 1.31 & 0.28 & 0.41 & 1.33 \\
\hline
\end{tabular}

\section{Experimental Program}

\subsection{Mix Compositions and Sample Preparation}

The mix compositions were developed to improve the strength and linear expansion of the investigated clay with further consideration of possible reduction in cement and the inclusion of SCM and fibres. In the first stage of mixing, the clay was mixed with $5 \%$ of PC by dry weight of soil. In the other stages of mixing, several mix compositions were considered with their corresponding average optimal moisture content (OMC) as shown in Table 3. The aim was to reduce cement content and replace with GGBS, lime, micro silica and synthetic fibres to develop an economic and environmentally friendly binder combination for soil treatment. Dry materials were mixed thoroughly at optimal moisture content in a variable speed Kenwood Chef Excel mixer for $2 \mathrm{~min}$ to enhance homogeneity before slowly adding the calculated amount of water. After proper mixing, wet mixed materials were placed into a cylindrical steel mould (50 $\mathrm{mm}$ in diameter and $100 \mathrm{~mm}$ in length) fitted with a collar to help accommodate all the material required for one sample. Samples placed in the cylindrical steel mould were equally compacted to maximum dry density (MDD) at optimal moisture (ASTM D698, 2012), using a hydraulic jack. The prefabricated mould ensured that the material was not over compacted. The cylinders were extruded using a steel plunger, wrapped in several runs of cling film, labelled and placed in polythene bags before being placed on a platform in sealed plastic containers. Water was always maintained below the platform to ensure that there was no evaporation from the samples. The plastic containers were then placed in an environmental chamber capable of maintaining temperatures to $20^{\circ} \mathrm{C}$ until they are ready for testing after 7- and 14-days moist curing period. Additional curing was carried out after 14 days, this time samples were cured under elevated temperatures (ET) of $30^{\circ}, 40^{\circ}$ and $50^{\circ} \mathrm{C}$ for $48 \mathrm{~h}$. 
Table 3. Mix proportion and materials.

\begin{tabular}{|c|c|c|c|c|c|c|c|c|}
\hline \multirow{2}{*}{ Mix Composition } & \multicolumn{7}{|c|}{ Materials } & \multirow[t]{2}{*}{$\begin{array}{c}\text { Average } \\
\text { OMC }\end{array}$} \\
\hline & Clay & $\begin{array}{c}\text { Portland } \\
\text { cement }\end{array}$ & Glass fibre & $\begin{array}{l}\text { Polyprop-ylene } \\
\text { fibre }\end{array}$ & Lime & GGBS & $\begin{array}{c}\text { Micro } \\
\text { silica }\end{array}$ & \\
\hline Untreated soil & $\sqrt{ }$ & - & - & - & - & - & - & 28.2 \\
\hline $5 \% \mathrm{PC}+0 \% \mathrm{~F}$ & $\sqrt{ }$ & $\sqrt{ }$ & - & - & - & - & - & 24.6 \\
\hline $5 \% \mathrm{PC}+0.4 \% \mathrm{GF}$ & $\sqrt{ }$ & $\sqrt{ }$ & $\sqrt{ }$ & - & - & - & - & \multirow{6}{*}{24.4} \\
\hline $5 \% \mathrm{PC}+0.4 \% \mathrm{PPF}$ & $\sqrt{ }$ & $\sqrt{ }$ & - & $\sqrt{ }$ & - & - & - & \\
\hline $5 \% \mathrm{PC}+0.6 \% \mathrm{GF}$ & $\sqrt{ }$ & $\sqrt{ }$ & $\sqrt{ }$ & - & - & - & - & \\
\hline $5 \% \mathrm{PC}+0.6 \% \mathrm{PPF}$ & $\sqrt{ }$ & $\sqrt{ }$ & - & $\sqrt{ }$ & - & - & - & \\
\hline $5 \% \mathrm{PC}+0.8 \% \mathrm{GF}$ & $\sqrt{ }$ & $\sqrt{ }$ & $\sqrt{ }$ & - & - & - & - & \\
\hline $5 \% \mathrm{PC}+0.8 \% \mathrm{PPF}$ & $\sqrt{ }$ & $\sqrt{ }$ & - & $\sqrt{ }$ & - & - & - & \\
\hline $2 \% \mathrm{PC}+3 \% \mathrm{SCM}+2 \%$ Lime $+0 \% \mathrm{~F}$ & $\sqrt{ }$ & $\sqrt{ }$ & - & - & $\sqrt{ }$ & $\sqrt{ }$ & - & 24.4 \\
\hline $2 \% \mathrm{PC}+3 \% \mathrm{SCM}+2 \%$ Lime $+0.4 \% \mathrm{GF}$ & $\sqrt{ }$ & $\sqrt{ }$ & $\sqrt{ }$ & - & $\sqrt{ }$ & $\sqrt{ }$ & - & \multirow{6}{*}{23.2} \\
\hline $2 \% \mathrm{PC}+3 \% \mathrm{SCM}+2 \%$ Lime $+0.4 \% \mathrm{PPF}$ & $\sqrt{ }$ & $\sqrt{ }$ & - & $\sqrt{ }$ & $\sqrt{ }$ & $\sqrt{ }$ & - & \\
\hline $2 \% \mathrm{PC}+3 \% \mathrm{SCM}+2 \%$ Lime $+0.6 \% \mathrm{GF}$ & $\sqrt{ }$ & $\sqrt{ }$ & $\sqrt{ }$ & - & $\sqrt{ }$ & $\sqrt{ }$ & - & \\
\hline $2 \% \mathrm{PC}+3 \% \mathrm{SCM}+2 \%$ Lime $+0.6 \% \mathrm{PPF}$ & $\sqrt{ }$ & $\sqrt{ }$ & - & $\sqrt{ }$ & $\sqrt{ }$ & $\sqrt{ }$ & - & \\
\hline $2 \% \mathrm{PC}+3 \% \mathrm{SCM}+2 \%$ Lime $+0.8 \% \mathrm{GF}$ & $\sqrt{ }$ & $\sqrt{ }$ & $\sqrt{ }$ & - & $\sqrt{ }$ & $\sqrt{ }$ & - & \\
\hline $2 \% \mathrm{PC}+3 \% \mathrm{SCM}+2 \%$ Lime $+0.8 \% \mathrm{PPF}$ & $\sqrt{ }$ & $\sqrt{ }$ & - & $\sqrt{ }$ & $\sqrt{ }$ & $\sqrt{ }$ & - & \\
\hline $2 \% \mathrm{PC}+3 \% \mathrm{SCM}+0 \% \mathrm{~F}$ & $\sqrt{ }$ & $\sqrt{ }$ & - & - & - & - & $\sqrt{ }$ & 24.1 \\
\hline $2 \% \mathrm{PC}+3 \% \mathrm{SCM}+0.4 \% \mathrm{GF}$ & $\sqrt{ }$ & $\sqrt{ }$ & $\sqrt{ }$ & - & - & - & $\sqrt{ }$ & \multirow{6}{*}{23.5} \\
\hline $2 \% \mathrm{PC}+3 \% \mathrm{SCM}+0.4 \% \mathrm{PPF}$ & $\sqrt{ }$ & $\sqrt{ }$ & - & $\sqrt{ }$ & - & - & $\sqrt{ }$ & \\
\hline $2 \% \mathrm{PC}+3 \% \mathrm{SCM}+0.6 \% \mathrm{GF}$ & $\sqrt{ }$ & $\sqrt{ }$ & $\sqrt{ }$ & - & - & - & $\sqrt{ }$ & \\
\hline $2 \% \mathrm{PC}+3 \% \mathrm{SCM}+0.6 \% \mathrm{PPF}$ & $\sqrt{ }$ & $\sqrt{ }$ & - & $\sqrt{ }$ & - & - & $\sqrt{ }$ & \\
\hline $2 \% \mathrm{PC}+3 \% \mathrm{SCM}+0.8 \% \mathrm{GF}$ & $\sqrt{ }$ & $\sqrt{ }$ & $\sqrt{ }$ & - & - & - & $\sqrt{ }$ & \\
\hline $2 \% \mathrm{PC}+3 \% \mathrm{SCM}+0.8 \% \mathrm{PPF}$ & $\sqrt{ }$ & $\sqrt{ }$ & - & $\sqrt{ }$ & - & - & $\sqrt{ }$ & \\
\hline
\end{tabular}

\subsection{Laboratory Testing}

\subsubsection{Unconfined Compression Test}

At the end of each of the moist curing periods, the treated samples were subjected to UCS tests. The UCS test was conducted in two stages after each curing periods. Firstly, the UCS test was conducted on samples cured under $20^{\circ} \mathrm{C}$ after 7 and 14 days respectively. The second phase of UCS test was conducted on 14 days cured samples subjected to elevated curing temperatures of $30^{\circ}, 40^{\circ}$ and $50{ }^{\circ} \mathrm{C}$ for $48 \mathrm{~h}$, and tested before cooling and after $24 \mathrm{~h}$ cooling period, to investigate the effect of a sudden rise and fall in curing temperature on UCS of the treated soils. Samples were placed on the platens of the HounMSiled compression test machine and loaded until failure at a strain rate of $1 \mathrm{~mm} / \mathrm{min}$ in accordance with BS EN 12390-4:2000 and ASTM D2166/D2166M (2013).

\subsubsection{Swell Test}

The samples tested for swelling were placed on a platform in a glass tank and covered with a lid fitted with dial gauges. The cylindrical samples were partially immersed in water to a depth of $10 \mathrm{~mm}$ above the sample base and swell was monitored for 7 days after 7 - and 14-days moist curing periods. The tank was placed in the environmental chamber where conditions were maintained at $20^{\circ} \mathrm{C}$ and $100 \%$ relative humidity. Values of linear axial swelling were recorded daily until no further expansion occurred, (BS EN 13286-49:2004). Both the moist curing environment and the soaking environment were closed sealed systems to reduce the availability of carbon dioxide and prevent carbonation of the lime, and clearly, excessive carbonation of the lime would reduce the amount of lime available for pozzolanic reaction and is, therefore, undesirable [12]. 


\subsection{Scanning Electron Microscope (SEM)}

Microscopic examination and measurement of soil pores have gained so much interest in recent years, partly because the analysis of images of soil fabric provides a straightforward investigation and analysis of soil void and porosity including clay particle degree of arrangement [42,43]. In this study, the micro-structural characteristics of the investigated soils were studied using scanning electron microscopy (SEM) to allow for microscopic examination and measurement of soil pores and orientation. Observations were made on dried and highly vacuumed samples using an acceleration voltage of up to $5 \mathrm{kV}$. In order to examine the micro-structural characteristics of the samples, scanning electron micrograph (SEM) was conducted on samples mixed with 5\%PC, $2 \% \mathrm{PC}+3 \% \mathrm{GGBS}$ and $2 \% \mathrm{PC}+3 \% \mathrm{MS}$ to understand the effect of cementation effect on soil pores and orientation.

\section{Results and Discussion}

\subsection{Unconfined Compressive Strength (UCS) of Samples Cured under Normal Temperature}

The effectiveness of the investigated mix compositions has been evaluated and presented in terms of UCS as an index in defining the extent of improvement of soils due to chemical treatment. According to the (ASTM D 4609), an effective soil stabilisation process using binders, should give a minimum target value of UCS equals $345 \mathrm{kPa}$. The UCS of the fibre reinforced clay blended with cement, lime, GGBS and micro silica, cured under $20^{\circ} \mathrm{C}$ is presented in Figures $2-4$. The results plotted in Figure 2 shows that after 14 days curing period, the UCS of samples mixed with $5 \%$ cement increases from $707 \mathrm{kPa}$ at $0 \%$ fibre content to $957 \mathrm{kPa}$ ) and $964 \mathrm{kPa}$ at $0.4 \%$ polypropylene and $0.8 \%$ glass fibre contents respectively. The increase in UCS with increasing cement and fibre contents agrees with the results of Chore and Vaidya, and Chenge et al. [44,45]. Over time, the high strength observed in the samples contaning $5 \% \mathrm{PC}$ and 0 to $0.8 \%$ fibre is due to the formation of calcium silicate hydrate gel (C-S-H gel) as expected. This result also shows that the presence of fibre does not interfer with the strength development and hence increased UCS. The reduction in cement content to $2 \%$ PC and inclusion of 3\% GGBS and $2 \%$ lime at 14days, show the UCS increased above the minimum target of UCS for a stabilised soil as recommended by the ASTM 4609, as shown in Figure 3, which again explains the effectiveness of the mix composition with reference to ASTM 4609. The observed increase in UCS is due to the cementation effect and the inclusion of lime to the pozzolanic supplementary cementitious material. However, from Figure 4, it is evident that the UCS of the mixture containing $2 \%$ PC and $3 \%$ micro silica falls below the minimum target irrespective of the fibre type and content due to reduced cement paste and bonding effect of soil-cement particles in the presence of a siliceous material with lower cementitious value, [46] after 7 and 14 days, respectively.

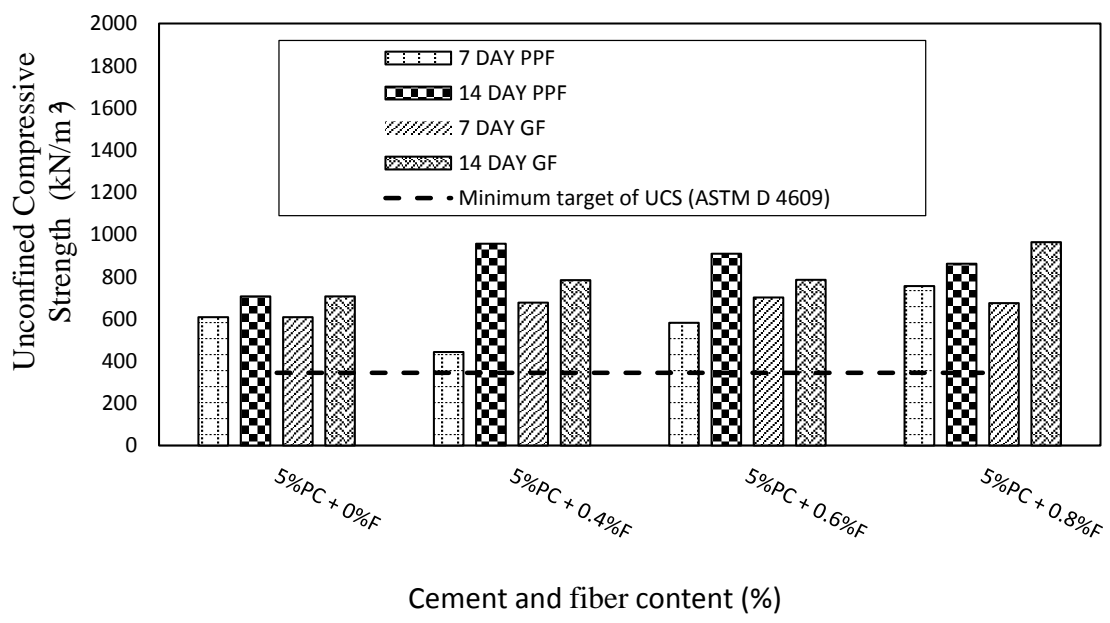

Figure 2. Unconfined compressive strength (UCS) test results for 5\%PC and fibre for 7 and 14 days of curing. 


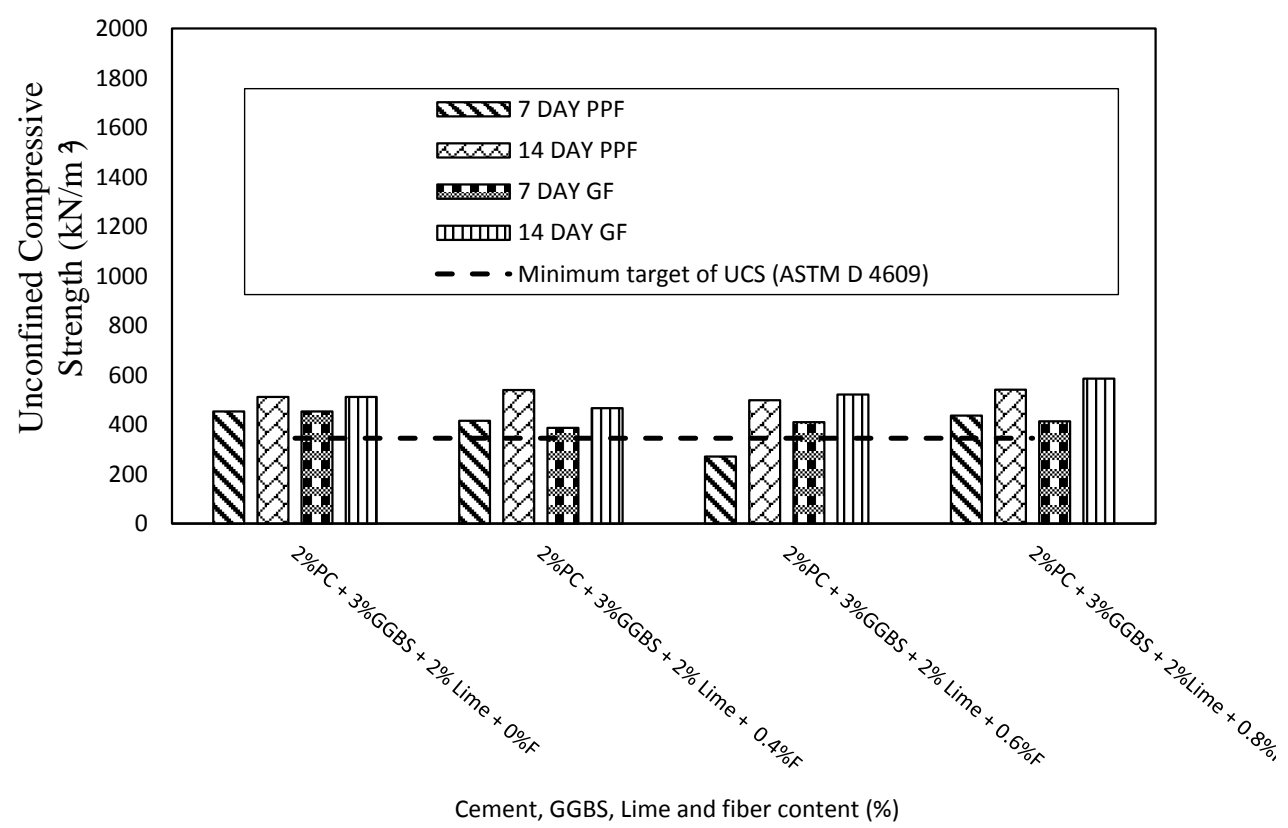

Figure 3. UCS results for $2 \%$ PC, 3\%GGBS, 2\%Lime and Fibre content after 7 and 14 days of curing.

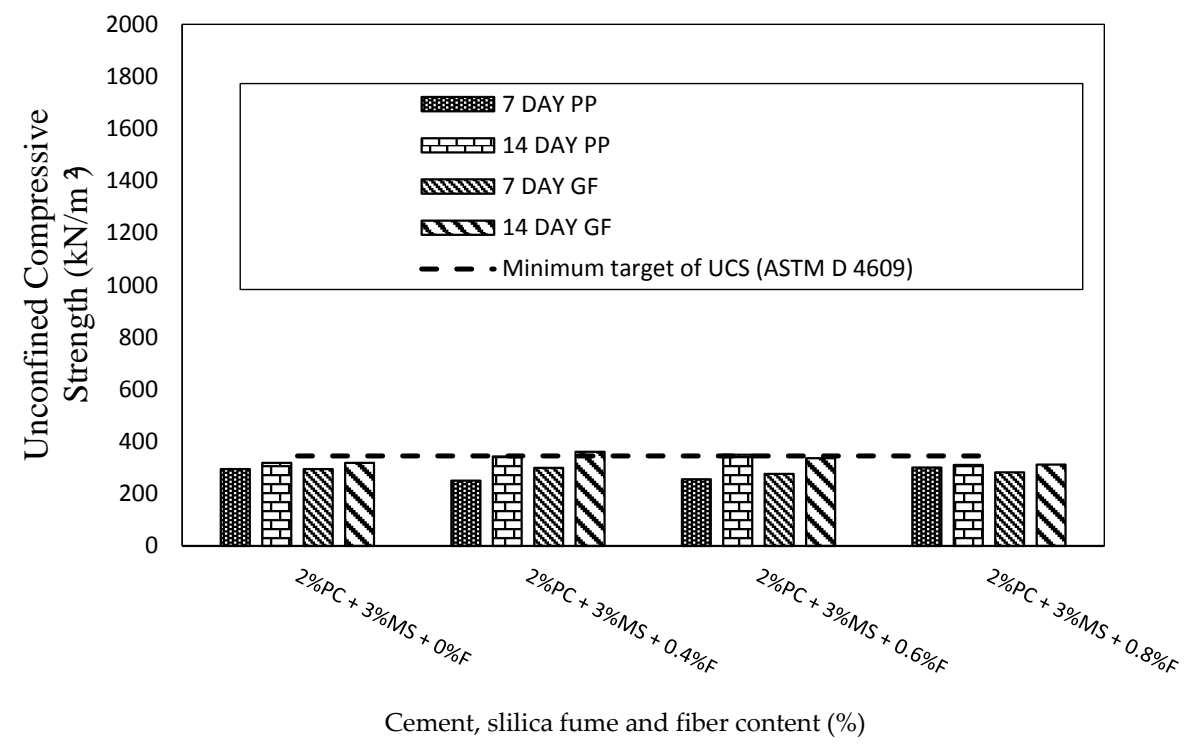

Figure 4. UCS results for $2 \% \mathrm{PC}, 3 \% \mathrm{MS}$ and fibre content after 7 and 14 days of curing.

\section{Effect of Elevated Temperature on UCS}

The UCS of samples cured for an additional $48 \mathrm{~h}$ under elevated curing temperatures of $30^{\circ}$, $40^{\circ}$ and $50{ }^{\circ} \mathrm{C}$ after 14 days of curing under $20^{\circ} \mathrm{C}$, were tested in two stages. Firstly, the effect of elevated curing temperature on UCS was investigated for samples tested immediately after the $48 \mathrm{~h}$ of ET curing and secondly, for samples tested after $24 \mathrm{~h}$ cooling period, respectively. The results of the effectiveness of the investigated clay-binder mixtures in terms of UCS are presented in Figures 5-8. The results presented in Figures 5-8 show that at a higher curing temperature between 30 and $50{ }^{\circ} \mathrm{C}$, and binder-fibre contents, the UCS of the reinforced clay increases in most cases under both testing conditions. Figures 5 and 6 show that in most cases, as temperature increases, the UCS of polypropylene fibre reinforced clay increases with an increase in cement and fibre contents respectively. However, the increase in UCS of the fibre-reinforced cemented clay can be attributed more to the bonding effect of the cement and other used cementitious materials (Lime, GGBS and MS) than the contribution of the polypropylene and glass fibres respectively. The UCS increases from $900 \mathrm{kPa}$ to $1200 \mathrm{kPa}$ and 
from $1200 \mathrm{kPa}$ to $1300 \mathrm{kPa}$ at 5\% cement and $0.8 \%$ polypropylene fibre contents for samples tested immediately after ET curing and samples tested after $24 \mathrm{~h}$ cooling period. This is due to an increase in the rate of hydration reaction at 30,40 and $50{ }^{\circ} \mathrm{C}$ and the bonding effect of the clay-binder-fibre system. According to Clare et al. [47] curing temperature up to $45^{\circ} \mathrm{C}$ is enough to result in an accelerated increase in strength of stabilised clay, and "the nature of the strength/age relationships obtained with the cohesive soils means that at temperatures up to $45^{\circ} \mathrm{C}$ one mechanism of hardening is involved; and that this is accelerated by increased temperature".

The UCS of the glass fibre-reinforced clay-binder mixtures reaches a maximum value of $1300 \mathrm{kPa}$ and $1400 \mathrm{kPa}$ at $5 \%$ cement and $0.8 \%$ glass fibre for samples tested immediately after ET curing and samples tested after $24 \mathrm{~h}$ cooling period respectively. The inclusion of fibres along with the cement only enhances the UCS as the curing time increases [27]. This statement is in line with the observations made in the present studies however, the present study has also considered an increase in temperature during the time the treated soils were cured, and it was found that the combination of the temperature effect and curing time, closely bonded and parked the particles together. Under the ET curing and cooling periods, the UCS of the investigated fibre-reinforced clay-binder samples increases more than that of the samples cured for 14 days under $20^{\circ} \mathrm{C}$. It was observed that the dimensions of the samples (50 $\mathrm{mm}$ diameter and $100 \mathrm{~mm}$ length) remained unchanged after curing under the investigated elevated temperatures due to the ability of polypropylene and glass fibres to control both volume change and any associated increase in porosity. The increase in UCS of the clay-binder-fibre system after cooling as shown in Figures 6 and 8 is an indication of the absence of both dehydration of the C-S-H gel and breakdown of the structure of the cement paste after curing under elevated temperatures up to to $50{ }^{\circ} \mathrm{C}$. This means that the presence of polypropylene and glass fibres in a clay-binder-fibre system does not interfere with the tricalcium silicate $\left(C_{3} S\right)$ responsible for early strength development and the bulk of C-S-H gel and calcium hydroxide $\left(\mathrm{Ca}(\mathrm{OH})_{2}\right)$ produced during the hydration process but rather reinforces and increases resistance to deformation. The reduction in cement content and inclusion of lime, GGBS and micro silica resulted in UCS values greater than the minimum target of UCS for evaluation of the effectiveness of any soil treatment activity as stated by the ASTM D 4609. The interaction between cement, GGBS, and lime with polypropylene and glass fibres under elevated curing temperatures, and the pozzolanic property and extreme fineness of micro silica all contributed to the enhanced performance of the fibre-reinforced clay-binder mixtures in terms of UCS. The increase in UCS above the minimum target of UCS can also be attributed to the ability of micro silica to bind and coat all clay particles which possess very little cementitious value [48].

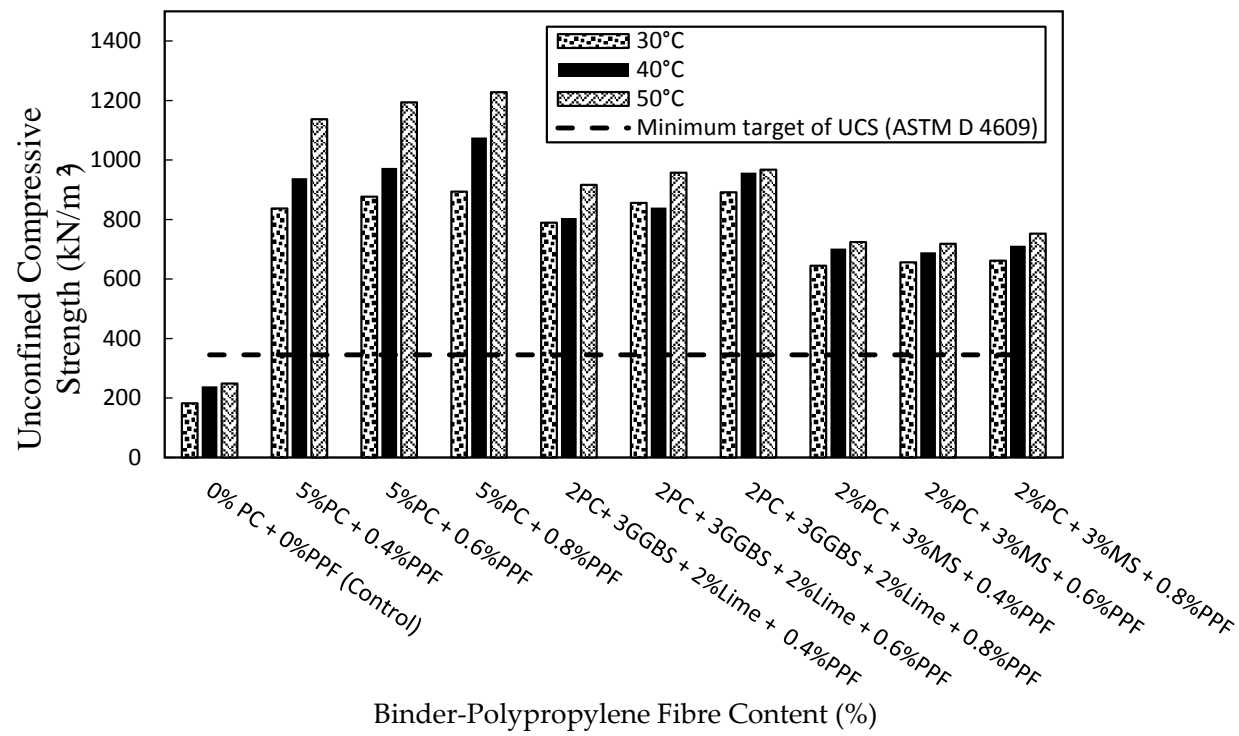

Figure 5. UCS of polypropylene and clay-binder mixtures tested immediately after $48 \mathrm{~h}$ elevated temperatures (ET) curing. 


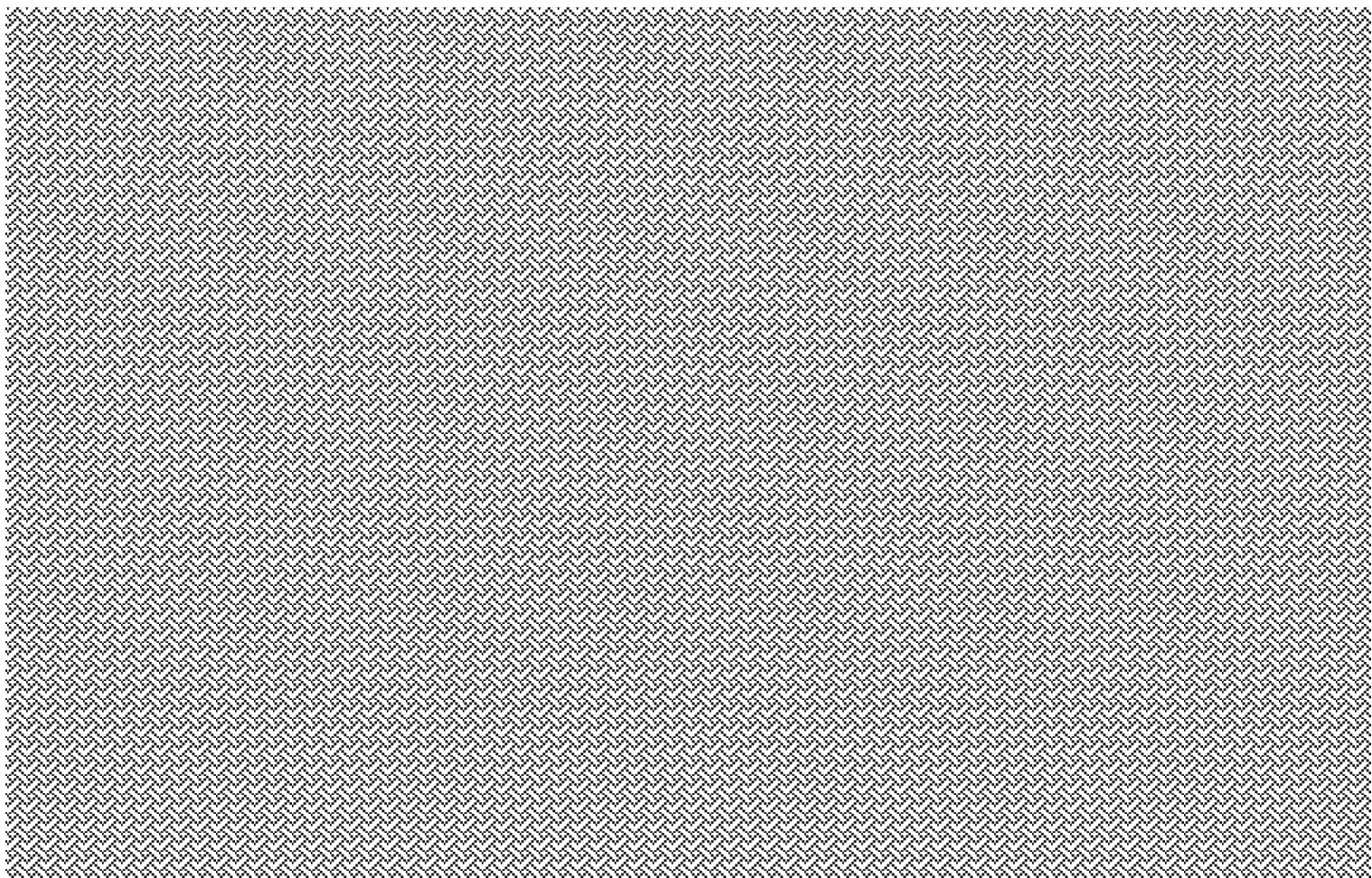

Binder-Polypropylene Fibre Content (\%)

Figure 6. UCS of polypropylene-reinforced clay-binder mixtures tested after $24 \mathrm{~h}$ cooling period.

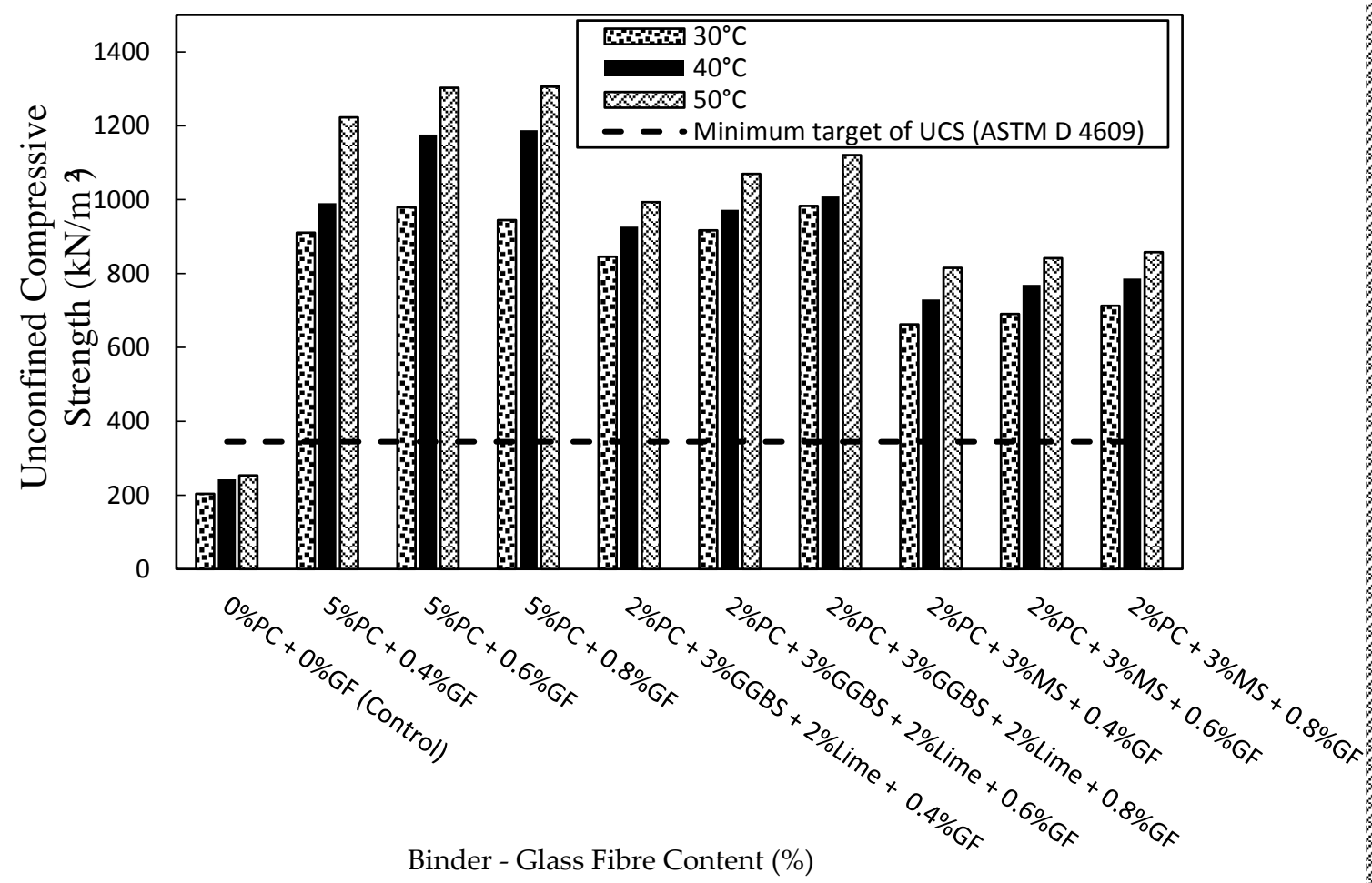

Figure 7. UCS of glass fibre-reinforced clay-binder mixtures tested immediately after ET curing. 


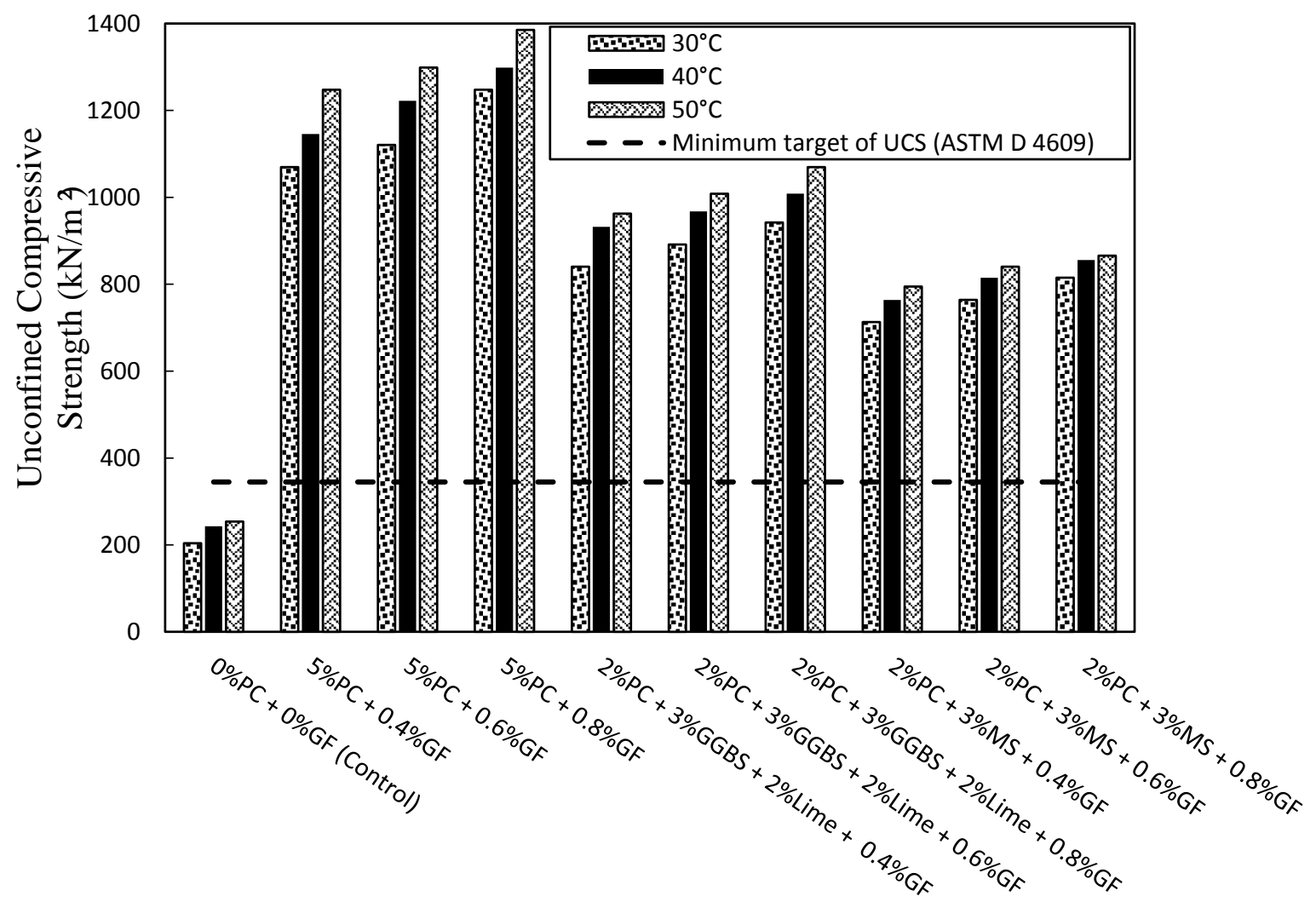

Binder-Glass Fibre Content (\%)

Figure 8. UCS of glass fibre-reinforced clay-binder mixtures tested after $24 \mathrm{~h}$ cooling period.

\subsection{Linear Expansion}

The Control mix with $0 \% \mathrm{PC}$ and $0 \% \mathrm{~F}$ achieved the highest linear expansion value of $7.92 \%$ after 7 days soaking period as shown in Figure 9a due to intercrystalline swelling of kaolinite clay in the presence of water. This clay seems to absorb much water within the first 2 days after which the expansion plateaus, indicating an equilibrium condition. However, the addition of $5 \% \mathrm{PC}$ and $0 \%$ fibre resulted to a drastic decrease in expansion from $7.92 \%$ to $0.2 \%$ as shown in Figure 9 a,b. Similarly, the inclusion of polypropylene and glass fibres show the linear expansion reduces from $7.92 \%$ to $0.48 \%$ and $0.32 \%$ at $0.8 \%$ polypropylene and and $0.6 \%$ glass fibre contents, respectively. The results presented in Figure $9 \mathrm{c}$ to $\mathrm{f}$ show that a reduction in cement content to $2 \% \mathrm{PC}$ and the inclusion of $3 \%$ micro silica and 3\% GGBS and 2\% lime, also reduces the linear expansion of the fibre reinforced clay compared to the linear expansion of the unreinforced control sample. At reduced cement content, the inclusion of $3 \%$ GGBS and $2 \%$ lime, reduce the linear expansion of the unreinforced kaolin clay from $7.92 \%$ to $0.87 \%$ at $0 \%$ fibre content. However, the inclusion of polypropylene and glass fibre reinforcements reduces the linear expansion of the unreinforced clay from $7.92 \%$ to $1.21 \%$ and $0.92 \%$ at $0.4 \%$ polypropylene and glass fibre content respectively. The reduction in expansion in the presence of cement, lime and GGBS can be attributed to the hydration process in PC when soaked in water and the formation of more calcium silicate hydrate gel (C-S-H gel) due to the presence of high amount of tricalcium silicate $\left(C_{3} S\right)$ in Portland cement leading to early strength gain and particle bonding, [49]. Also, the addition of fibres in the soil means that when swelling occurs the fibres are stretched creating tension in the fibres which causes it to resist swelling. According to Soltani et al. [30], the greater the contact between the fibres and soil particles, the greater the resistance to swelling. However, it was observed that the application of polypropylene and glass fibres reduces linear expansion of the unreinforced clay but, the mix compositions with $0 \%$ fibre content achieved fairly lower expansion than other mixtures except for mix composition containing $(2 \% \mathrm{PC}+3 \% \mathrm{MS}+0 \% \mathrm{GF})$ due to low silic fume content as seen in 
Figure 9e,f. However, Al-Soudany [50] reported that free swell and swell pressure can decrease by increasing the percentage of micro silica between 3\% and 7\%. In the present study, the inclusion of polypropylene and glass fibres resulted to a reduction in swell at higher fibre contents compared to the swell potential of the original soil. Therefore, polypropylene and glass fibres have the potential of reducing swelling in clay when mixed with GGBS, micro silica, $2 \%$ lime and $2 \%$ cement.
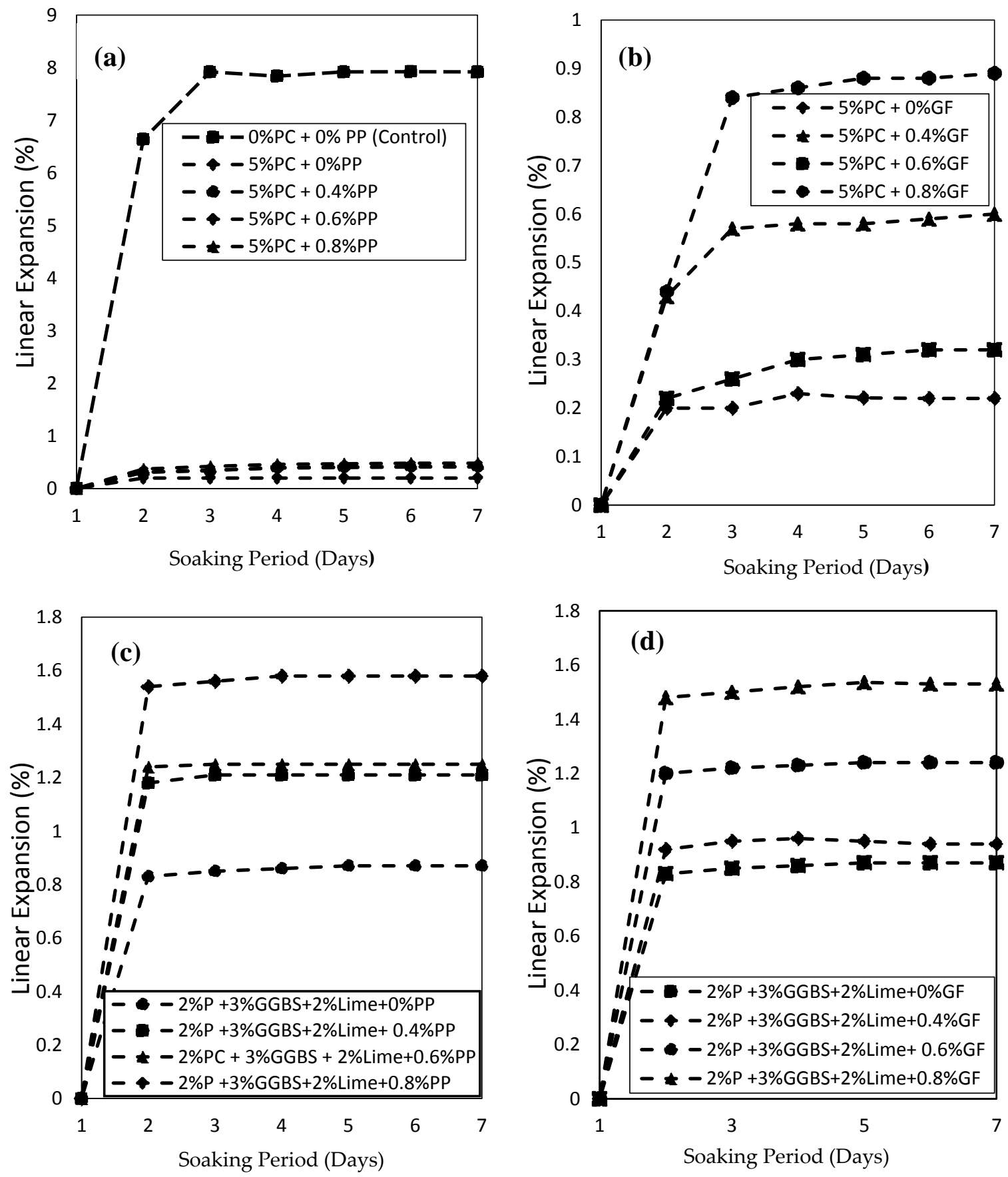

Figure 9. Cont. 

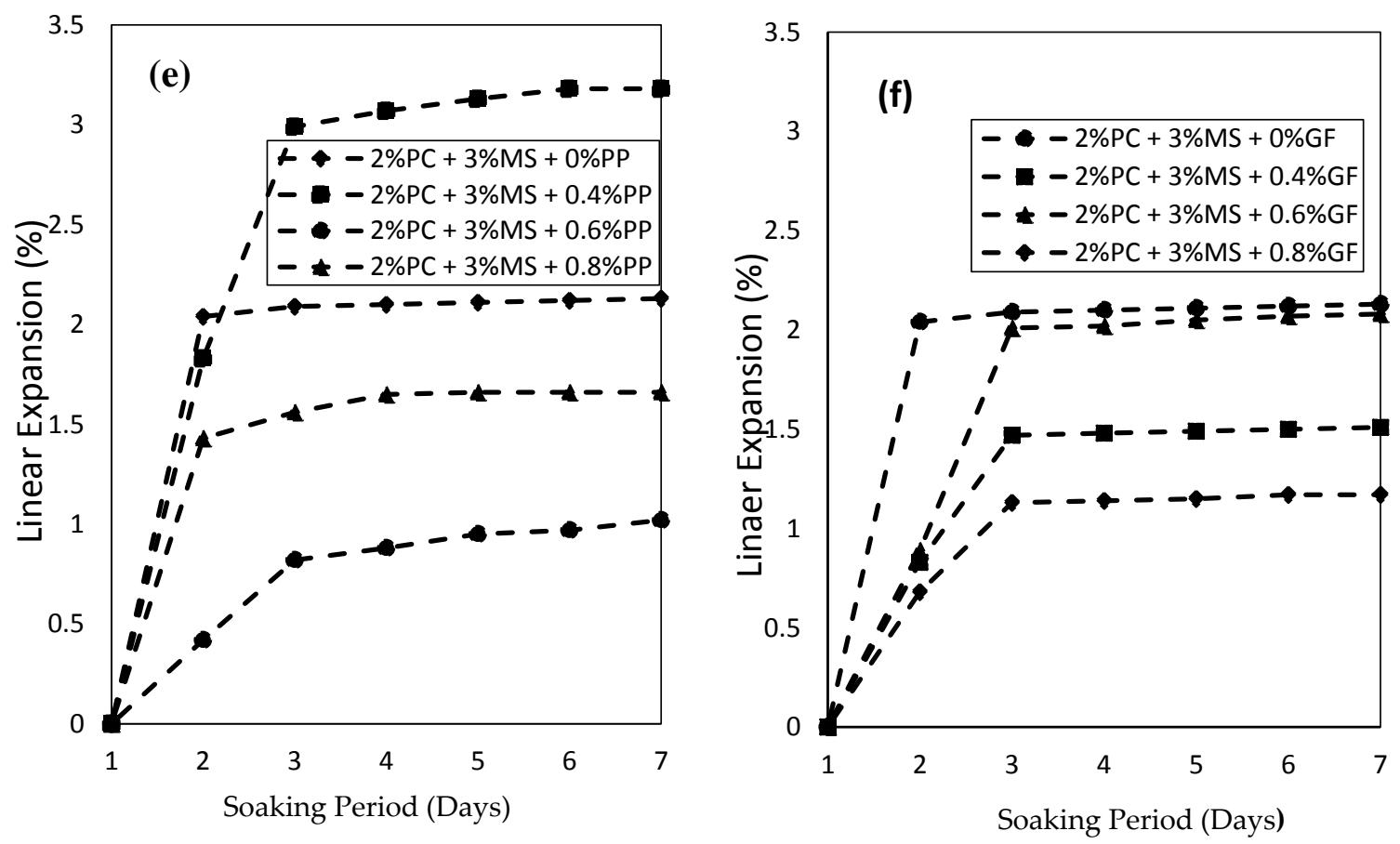

Figure 9. (a-f) Linear expansion of the clay-binder mixtures versus soaking time.

\subsection{Scanning Electron Microscopy (SEM) of Treated Soils}

The SEM images presented in Figure 10a-d, show the micro-structural orientation of the unreinforced and reinforced clay blended with PC and supplementary cementitious materials such as GGBS and micro silica. Figure 10a shows the presence of pore and hollow cavities, for the unreinforced kaolin clay while several aggregated soil particles of varying shape and size, gel formation are observed with the addition of 5\%PC as shown in Figure 10b. Information on particle size distribution of the investigated clay is as previously presented in Figure 1. The formation of the cementitious hydrated compound can be attributed to the development of a cementitious compound called calcium silicate hydrate (CSH gel) during the hydration of cement. This increases the bonding between particles, closing up and filling pores and leading to the formation of a more closely parked soils with higher strength and lower expansion. According to Jha and Sivapullaiah, [42], the binding and coating of aggregated soil particles leads to the formation of densely packed and compacted structure, whereas relatively lesser white patches are observed, reflecting the consumption of cementitious gel in filling and binding of particles. The hydration products of cement hydration surround and connect clay particles together to form a denser structure and reduced voids. Figure 10c shows the SEM image of the reinforced clay with $2 \% \mathrm{PC}+3 \% \mathrm{GGBS}+2 \%$ lime $+0 \% \mathrm{~F}$, with a dense matrix which in turn resulted to a reduction in expansion. At reduced cement content of $2 \% \mathrm{PC}$ and inclusion of $3 \%$ micro silica, the microstructure of the reinforced clay shows more of a conglomerated attributes living some pore and hollow cavity at $0 \%$ fibre content as shown in Figure 10d. 

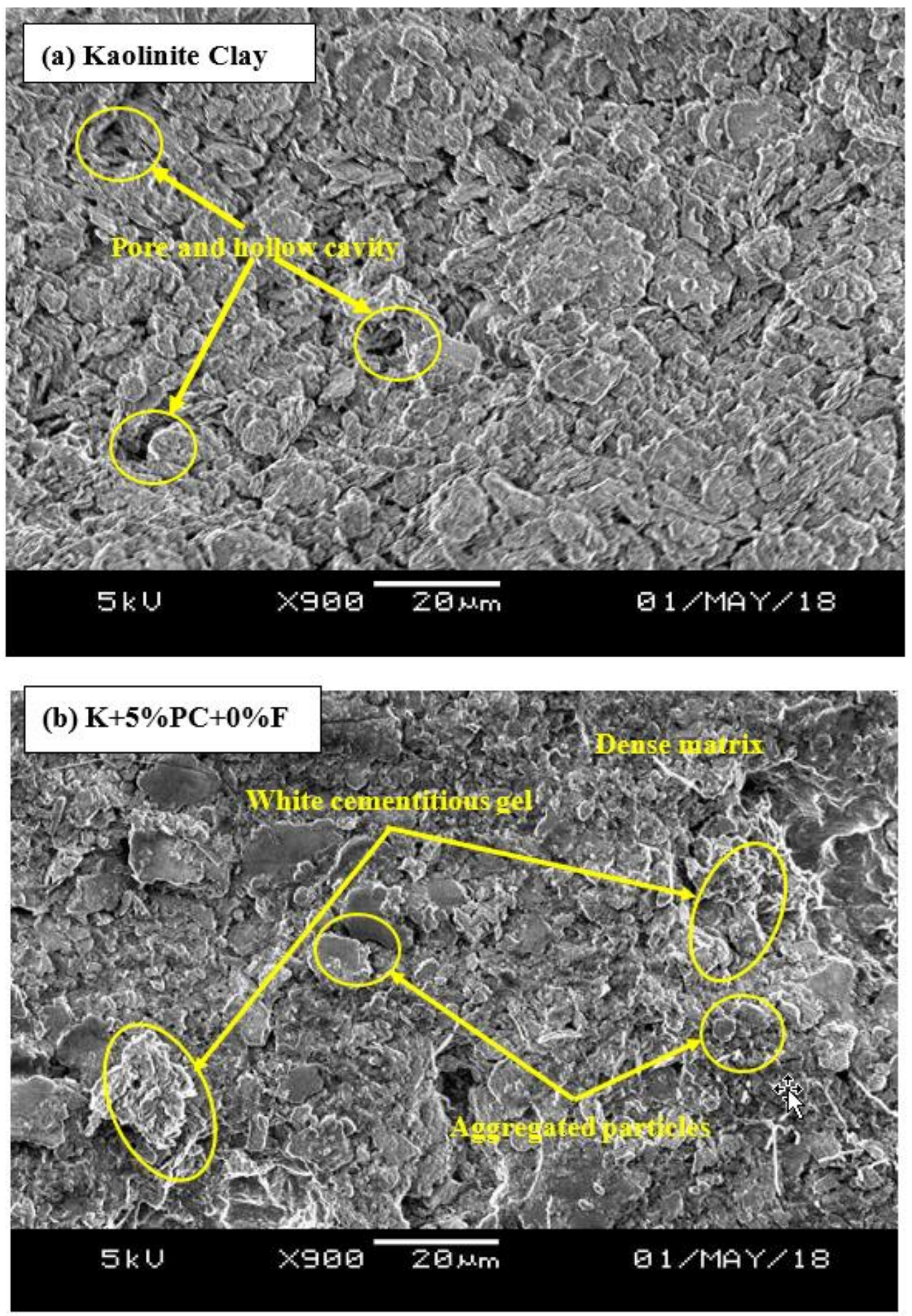

Figure 10. Cont. 

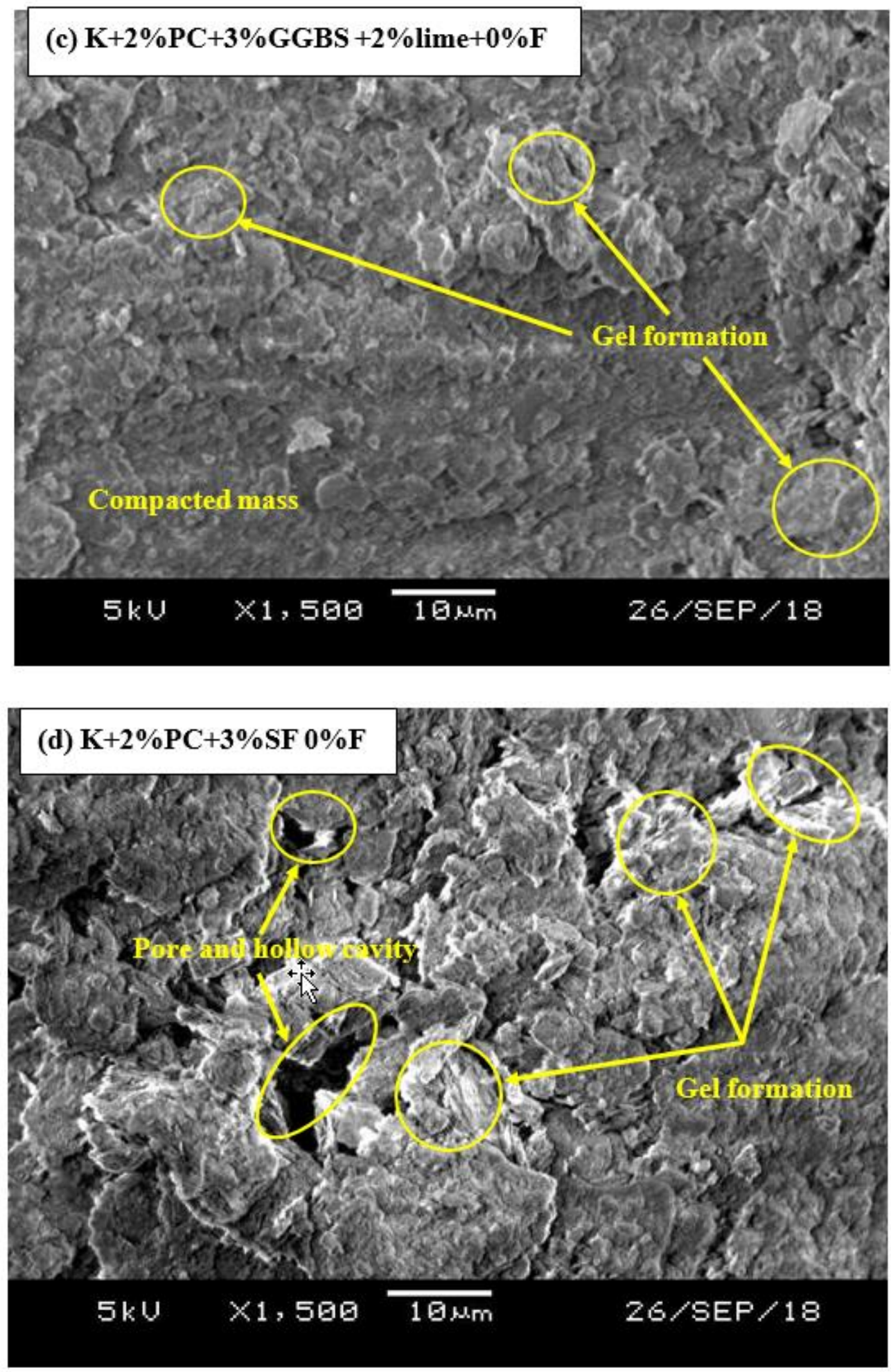

Figure 10. (a-d) SEM images of fibre-reinforced clay blended with PC and SCM.

\subsection{Geological Engineering Significance}

Clay soils often present difficulties in construction operations such as sliding and swelling during or after construction and can lead to significant geological disasters and geological environmental damages. However, the susceptibility of clayey soils to sliding and swelling can be controlled by enhancing the engineering properties of the clay by the addition of small percentages, by weight, 
of cement to produce an improved clay-cement material that can be used for construction purposes. The experimental results obtained from the present study indicate that the susceptibility of swelling clays to landsliding during construction activities can be reduced drastically by stabilisation with synthetic fibres blended with GGBS and micro silica based on the level of improvement achieved. Compared to that of the untreated clay which will exhibit significant swelling and shrinkage behaviour in the presence of water due to the amounts of swelling clay minerals. The unconfined compressive strengths and shear strengths of untreated clay soils will decrease dramatically upon saturation which may lead to landsliding, for example, during construction of high-speed railways. However, the present study has shown that the use of synthetic fibre and by-product cementitious materials have the ability to increase the strength of clay soils when mixed together at optimal moisture content due to the binding and cementation of clay particles by the cementitious by-products in the presence of reduced amount of cement. This implies that synthetic fibres blended with by-product cementitious materials can find application in stabilisation and improvement of the engineering properties of clayey soil slopes to eliminate possible geological disasters and geological environmental damages that may occur during or after construction. Nonetheless, it is important also to state that the properties of clay in a clay-cement mixture can be affected by the type of minerals present in the clay. Therefore, the clay type used in this study (kaolin clay) may appear to have little effect on the hydration and hardening process and hence, the significant increase in strength and reduction in swelling potential. It is recommended that the application of these synthetic fibres blended with GGBS and micro silica mixed with a small amount of cement be extended to the stabilisation of clay of dominantly montmorillonite due to higher expansive lattice and possibly more significant influence on the hardening process.

\section{Conclusions}

In the present study, a series of tests has been performed on clayey soil mixed with different percentages of stabilisers; cement, lime and micro silica and synthetic fibres; polypropylene and glass fibres to investigate the characteristics of the stabilized soils. The mechanical properties and microstructure of the fibre-reinforced clay blended with cement, lime, GGBS and micro silica were studied. The following conclusions may be drawn:

1. An increase in polypropylene and glass fibre contents caused an increase in UCS but brought on the reduction of linear expansion at fibre content up to $0.8 \%$ for cement-clay mixture reinforced with $5 \% \mathrm{PC}$. The use of $0.4-0.8 \%$ polypropylene and glass fibre contents in reinforcing cement-clay mixture at $5 \%$ cement content caused an increase in UCS values above minimum UCS target value according to ASTM 4609 after 7 and 14 days curing at 20 to $50{ }^{\circ} \mathrm{C}$ temperature.

2. At reduced cement content of $2 \%$, cement-clay mixtures blended with lime and GGBS required 14 days curing period under $20^{\circ} \mathrm{C}$ to achieve UCS value greater than minimum UCS target value according to ASTM 4609; however, at elevated curing temperature of 30 to $50{ }^{\circ} \mathrm{C}$, higher UCS values were obtained after 7 days' curing period. For the samples cured under elevated curing temperature, the observed increase in unconfined compressive strength upon reduction in cement content implies that less PC should be needed to stabilise clay soils under tropical than under temperate conditions.

3. At reduced cement content of $2 \% \mathrm{PC}$ and inclusion of $3 \%$ micro silica, the microstructure of the fibre-reinforced clay showed a denser matrix with closely parked particles at $0.8 \%$ fibre content compared to a microstructure with pore and hollow cavity at $0 \%$ fibre content for $2 \% \mathrm{PC}+3 \% \mathrm{MS}$ mixture.

4. At elevated curing temperature up to $50{ }^{\circ} \mathrm{C}$, the addition of polypropylene and glass fibres in cement-clay mixtures blended with GGBS and micro silica caused an increase in UCS even at reduced cement content of $2 \%$.

5. The increase in UCS is due to the development of a cementitious compound called the calcium silicate hydrate (CSH gel) during the hydration of cement and subsequent increases in the bonding 
between particles, filling of pores and formation of a more closely packed soils. Therefore, this new clean production of fibre-reinforced cement-clay mixture blended with industrial by-product materials can be applied in a wide range of soil reinforcements.

\section{Compliance with Ethical Standards}

Author Contributions: Conceptualization, S.J.A., J.O., S.Y.A. and S.N.; Data curation, S.J.A. and S.Y.A.; Formal analysis, S.J.A., E.U.E., J.O. and S.Y.A.; Investigation, S.J.A., E.U.E., S.Y.A. and S.N.; Methodology, S.J.A., J.O. and E.U.E.; Project administration, S.J.A., E.U.E., J.O. and S.N.; Resources, S.J.A., E.U.E., J.O., S.Y.A. and S.N.; Supervision, J.O. and S.N.; Validation, S.N.; Writing-original draft, S.J.A.; Writing-review \& editing, S.J.A., E.U.E., J.O., S.Y.A. and S.N. All authors have read and agreed to the published version of the manuscript.

Funding: The authors have not received any external funding for this work.

Conflicts of Interest: The authors declare that they have no conflict of interest.

\section{References}

1. Modarres, A.; Nosoudy, Y.M. Clay Stabilization Using Coal Waste and Lime-Technical and Environmental Impacts. Appl. Clay Sci. 2015, 116-117, 281-288. [CrossRef]

2. Abbey, S.J.; Ngambi, S.; Coakley, E. Effect of Cement and By-Product Material Inclusion on Plasticity of Deep Mixing Improved Soils. Int. J. Civ. Eng. Technol. 2016, 7, 265-274.

3. Farouk, A.; Shahien, M.M. Ground Improvement Using Soil-Cement Columns: Experimental Investigation. Alexandria Eng. J. 2013, 52, 733-740. [CrossRef]

4. Abbey, S.J.; Eyo, E.U.; Ng'ambi, S. Swell and Microstructural Characteristics of High-Plasticity Clay Blended with Cement. Bull. Eng. Geol. Environ. 2019. [CrossRef]

5. Nidzam, R.M.; Kinuthia, J.M. Sustainable Soil Stabilisation with Blastfurnace Slag-A Review. Proc. Inst. Civ. Eng.-Constr. Mater. 2010, 163, 157-165. [CrossRef]

6. Higgins, D. Soil Stabilisation with Ground Granulated Blastfurnace Slag; UK Cementitious Slag Makers Association (CSMA): London, UK, 2005.

7. Eyo, E.U.; Ngambi, S.; Abbey, S.J. Investigative Study of Behaviour of Treated Expansive Soil Using Empirical Correlations. In International Foundation Congress and Equipment Expo 5-10 March; American Society of Civil Engineers (ASCE): Orlando, FL, USA, 2018; pp. 373-384.

8. Abbey, S.J.; Ng'ambi, S.; Ganjian, E. Development of Strength Models for Prediction of Unconfined Compressive Strength of Cement/by-Product Material Improved Soils. Geotech. Test. J. 2017, 40, 928-935. [CrossRef]

9. Eyo, E.U.; Ngambi, S.; Abbey, S.J. Investigative Modelling of Behaviour of Expansive Soils Improved Using Soil Mixing Technique. Int. J. Appl. Eng. Res. 2017, 12, 3828-3836.

10. Eyo, E.U.; Ngambi, S.; Abbey, S.J. Performance of Clay Stabilized by Cementitious Materials and Inclusion of Zeolite / Alkaline Metals-Based Additive. Transp. Geotech. 2020, 23. [CrossRef]

11. Abbey, S.J.; Ngambi, S.; Olubanwo, A.O. Effect of Overlap Distance and Chord Angle on Performance of Overlapping Soil-Cement Columns. Int. J. Civ. Eng. Technol. 2017, 8, 627-637.

12. Wild, S. Effects of Ground Granulated Blast Furnace Slag (GGBS) on the Strength and Swelling Properties of Lime-Stabilized Kaolinite in the Presence of Sulphates. Clay Miner. 1996, 31, 423-433. [CrossRef]

13. Cokca, E.; Yazici, V.; Ozaydin, V. Stabilization of Expansive Clays Using Granulated Blast Furnace Slag (GBFS) and GBFS-Cement. Geotech. Geol. Eng. 2009, 27, 489-499. [CrossRef]

14. James, R.; Kamruzzaman, A.H.M.; Haque, A.; Wilkinson, A. Behaviour of Lime-Slag-Treated Clay. Proc. Inst. Civ. Eng.-Gr. Improv. 2008, 161, 207-216. [CrossRef]

15. Azzam, W.R. Utilization of Polymer Stabilization for Improvement of Clay Microstructures. Appl. Clay Sci. 2014, 93-94, 94-101. [CrossRef]

16. Soltani, A.; Taheri, A.; Khatibi, M.; Estabragh, A.R. Swelling Potential of a Stabilized Expansive Soil: A Comparative Experimental Study. Geotech. Geol. Eng. 2017, 35, 1717-1744. [CrossRef]

17. Haase, H.; Schanz, T. Compressibility and Saturated Hydraulic Permeability of Clay-Polymer Composites -Experimental and Theoretical Analysis. Appl. Clay Sci. 2016, 130, 62-75. [CrossRef] 
18. Correia, A.A.S.; Venda Oliveira, P.J.; Custódio, D.G. Effect of Polypropylene Fibres on the Compressive and Tensile Strength of a Soft Soil, Artificially Stabilised with Binders. Geotext. Geomembr. 2015, 43, 97-106. [CrossRef]

19. Olgun, M. Effects of Polypropylene Fiber Inclusion on the Strength and Volume Change Characteristics of Cement-Fly Ash Stabilized Clay Soil. Geosynth. Int. 2013, 20, 263-275. [CrossRef]

20. Tang, C.-S.; Shi, B.; Cui, Y.-J.; Liu, C.; Gu, K. Desiccation Cracking Behavior of Polypropylene Fiber-Reinforced Clayey Soil. Can. Geotech. J. 2012, 49, 1088-1101. [CrossRef]

21. Puppala, A.J.; Musenda, C. Effects of Fiber Reinforcement on Strength and Volume Change in Expansive Soils. Transp. Res. Rec. J. Transp. Res. Board 2007, 1736, 134-140. [CrossRef]

22. Abdi, M.R.; Parsapajouh, A.; Arjomand, M.A. Effects of Random Fiber Inclusion on Consolidation, Hydraulic Conductivity, Swelling, Shrinkage Limit and Desiccation Cracking of Clays. Int. J. Civ. Eng. 2008, 6, $284-292$.

23. Ikizler, S.B.; Aytekin, M.; Nas, E. Laboratory Study of Expanded Polystyrene (EPS) Geofoam Used with Expansive Soils. Geotext. Geomembr. 2008, 26, 189-195. [CrossRef]

24. Al-Akhras, N.M.; Attom, M.F.; Al-Akhras, K.M.; Malkawi, A.I.H. Influence of Fibers on Swelling Properties of Clayey Soil. Geosynth. Int. 2008, 15, 304-309. [CrossRef]

25. Punthutaecha, K.; Puppala, A.J.; Vanapalli, S.K.; Inyang, H. Volume Change Behaviors of Expansive Soils Stabilized with Recycled Ashes and Fibers. J. Mater. Civ. Eng. 2006, 18, 616-617. [CrossRef]

26. Wang, Y.; Cui, Y.J.; Tang, A.M.; Tang, C.S.; Benahmed, N. Effects of Aggregate Size on Water Retention Capacity and Microstructure of Lime-Treated Silty Soil. Géotechnique Lett. 2015, 5, 269-274. [CrossRef]

27. Tang, C.; Shi, B.; Gao, W.; Chen, F.; Cai, Y. Strength and Mechanical Behavior of Short Polypropylene Fiber Reinforced and Cement Stabilized Clayey Soil. Geotext. Geomembr. 2007, 25, 194-202. [CrossRef]

28. Zaimoglu, A.S.; Yetimoglu, T. Strength Behavior of Fine Grained Soil Reinforced with Randomly Distributed Polypropylene Fibers. Geotech. Geol. Eng. 2012, 30, 197-203. [CrossRef]

29. Consoli, N.C.; Arcari Bassani, M.A.; Festugato, L. Effect of Fiber-Reinforcement on the Strength of Cemented Soils. Geotext. Geomembr. 2010, 28, 344-351. [CrossRef]

30. Soltani, A.; Deng, A.; Taheri, A. Swell-Compression Characteristics of a Fiber-Reinforced Expansive Soil. Geotext. Geomembr. 2018, 46, 183-189. [CrossRef]

31. Viswanadham, B.V.S.; Phanikumar, B.R.; Mukherjee, R.V. Swelling Behaviour of a Geofiber-Reinforced Expansive Soil. Geotext. Geomembr. 2009, 27, 73-76. [CrossRef]

32. Syed, M.; Guharay, A. Stabilization of Expansive Soil Reinforced with Polypropylene and Glass Fiber in Cement and Alkali Activated Binder. In Advancements in Unsaturated Soil Mechanics; Hoyos, L., Shehata, H., Eds.; Springer International Publishing: Cham, Switzerland, 2020; pp. 41-55.

33. Ateş, A. Mechanical Properties of Sandy Soils Reinforced with Cement and Randomly Distributed Glass Fibers (GRC). Compos. Part B Eng. 2016, 96, 295-304. [CrossRef]

34. Ahmad, F.; Mujah, D.; Hazarika, H.; Safari, A. Assessing the Potential Reuse of Recycled Glass Fibre in Problematic Soil Applications. J. Clean. Prod. 2012, 35, 102-107. [CrossRef]

35. Ali, G.; Saeed, K.; Parham, R. Stabilization of Silty Sand Soils with Lime and Micro silica Admixture in Presence of Sulfates. In Proceedings of the 14th Pan-American Conference on Soil Mechanics and Geotechnical Engineering, Toronto, ON, Canada, 2-6 October 2011.

36. Al-azzawi, A.A.; Daud, K.A.; Abdul Sattar, M.A. Effect of Micro silica Addition on the Behavior of Silty-Clayey Soils. J. Eng. Dev. 2012, 16, 92-105.

37. Long, G.; Li, L.; Li, W.; Ma, K.; Dong, W.; Bai, C.; Zhou, J.L. Enhanced Mechanical Properties and Durability of Coal Gangue Reinforced Cement-Soil Mixture for Foundation Treatments. J. Clean. Prod. 2019, 231, 468-482. [CrossRef]

38. Kalkan, E. Influence of Micro silica on the Desiccation Cracks of Compacted Clayey Soils. Appl. Clay Sci. 2009, 43, 296-302. [CrossRef]

39. Goodarzi, A.R.; Akbari, H.R.; Salimi, M. Enhanced Stabilization of Highly Expansive Clays by Mixing Cement and Micro silica. Appl. Clay Sci. 2016, 132-133, 675-684. [CrossRef]

40. Alrubaye, A.J.; Hasan, M.; Fattah, M.Y. Stabilization of Soft Kaolin Clay with Micro silica and Lime. Int. J. Geotech. Eng. 2017, 11, 90-96. [CrossRef]

41. ACI, C. 230. State-of-the-Art Report on Soil-Cement. Mater. J. 1990, 87, 395-417.

42. Jha, A.K.; Sivapullaiah, P.V. Mechanism of Improvement in the Strength and Volume Change Behavior of Lime Stabilized Soil. Eng. Geol. 2015, 198, 53-64. [CrossRef] 
43. Jamshowang, P.; Nuansrithong, N.; Voottipruex, P.; Songpiriyakij, S. Laboratory Investigations on the Swelling Behavior of Composite Expansive Clays Stabilized with Shallow and Deep Clay-Cement Mixing Methods. Appl. Clay Sci. 2017, 148, 83-94. [CrossRef]

44. Chore, H.S.; Vaidya, M.K. Strength Characterization of Fiber Reinforced Cement-Fly Ash Mixes. Int. J. Geosynth. Gr. Eng. 2015, 1, 1-8. [CrossRef]

45. Cheng, Q.; Zhang, J.; Zhou, N.; Guo, Y.; Pan, S. Experimental Study on Unconfined Compression Strength of Polypropylene Fiber Reinforced Composite Cemented Clay. Crystals 2020, 10, 247. [CrossRef]

46. Mohammed, Y.F.; Aamal, A.A.; Mather, M.J. Characteristics of Clays Stabilized with Lime-Silica Fume Mix. Ital. J. Geosci. 2015, 134, 104-113. [CrossRef]

47. Clare, K.E.; Pollard, A.E. The Effect of Curing Temperature on the Compressive Strenght Of Soil-Cement Mixtures. Géotechnique 1954, 4, 97-106. [CrossRef]

48. Abd El-Aziz, M.; Abo-Hashema, M.; El-Shourbagy, M. “The effect of Lime Silica Fume Stabilizer on Engineering Properties of Clay Subgrade". In Proceedings of the Fourth Mansoura International Engineering Conference (4th IEC), Faculty of Engineering, Mansoura, Egypt, 1-4 April 2004.

49. Saghiri, M.A.; Orangi, J.; Asatourian, A.; Gutmann, J.L.; Garcia-Godoy, F.; Lotfi, M.; Sheibani, N. Calcium silicate-based cements and functional impacts of various constituents. Dent. Mater. J. 2017, 36, 8-18. [CrossRef] [PubMed]

50. Al-Soudany, K. Remediation of Clayey Soil Using Silica Fume. In Proceedings of the 3rd International Conference on Buildings, Construction and Environmental Engineering, BCEE3-2017, Sharm el-Shiekh, Egypt, 23-25 October 2017. [CrossRef]

(C) 2020 by the authors. Licensee MDPI, Basel, Switzerland. This article is an open access article distributed under the terms and conditions of the Creative Commons Attribution (CC BY) license (http://creativecommons.org/licenses/by/4.0/). 